\title{
Pengembangan Buku Ajar Bahasa Inggris Kelas 3 MI/SD Berbasis Islami
}

\author{
Fira Nadliratul Afrida \\ Institut Pesantren Mathali'ul Falah Pati \\ Email korespondensi: firanadliratulafrida@ipmafa.ac.id
}

\begin{abstract}
The development of textbooks is one of the main factors in the success of learning, this Islamicbased English textbook has a characteristic that is contextual and Islamic-based material which is equipped with 4 aspects of language skills. The objectives of this study were to developing Islamic-based English textbooks and researching the validity and attractiveness of the developed textbooks. The research method used is research and development using the Borg \& Gall design. The results of this study indicate that the development of English textbooks obtains good qualifications, as evidenced by the results of validation by material experts with a percentage of $80 \%$, design experts with a percentage of $92 \%$, class teachers with a percentage of $94 \%$. Textbooks have a high level of interest as evidenced by the results of interviews and questionnaires to students with a percentage of $90.04 \%$, so that the textbooks have met the aspects of development \& needs in the learning process.
\end{abstract}

Keyword: Textbook development, English for Elementary Students, Islamic

\begin{abstract}
Abstrak
Pengembangan buku ajar menjadi salah satu faktor utama dalam keberhasilan pembelajaran, Buku ajar bahasa inggris berbasis islami ini mempunyai ciri khas yaitu materi berbasis kontekstual dan keislaman yang dilengkapi dengan 4 aspek keterampilan berbahasa. Penelitian ini bertujuan untuk mengembangkan buku ajar bahasa inggris berbasis islami dan meneliti validitas serta kemenarikan buku ajar yang dikembangkan. Metode penelitian yang digunakan adalah penelitian dan pengembangan dengan menggunakan desain Borg \& Gall. Hasil penelitian ini menunjukkan bahwa pengembangan buku ajar bahasa inggris memperoleh kualifikasi yang baik, dibuktikan dengan hasil validasi oleh ahli materi dengan persentase $80 \%$, ahli desain dengan persentase 92\%, guru kelas dengan persentase 94\%. Buku ajar memiliki tingkat kemenarikan yang tinggi dibuktikan dengan hasil wawancara dan angket kepada peserta didik dengan persentase 90,04\%, Sehingga buku ajar telah memenuhi aspek-aspek dalam pengembangan \& kebutuhan dalam proses pelaksanaan pembelajaran.
\end{abstract}

Kata kunci: Pengembangan Buku Ajar, Bahasa Inggris MI/SD, Islami

\section{A. Pendahuluan}

Bahasa inggris di Sekolah Dasar atau Madrasah Ibtidaiyah merupakan Bahasa asing dikalangan peserta didik karena Bahasa tersebut tidak digunakan dalam komunikasi sehari-hari atau pengantar dalam pembelajaran. Penguasaan Bahasa inggris harus dimulai sejak dini terutama pada jenjang sekolah dasar, 
karena Bahasa inggris merupakan Bahasa internasional yang digunakan untuk komunikasi di seluruh dunia. Beberapa keterampilan berbahasa yang harus dikuasai dalam pembelajaran di sekolah dasar diantaranya: membaca, menulis, berbicara dan menyimak. Keterampilan tersebut harus ditunjang dengan minat peserta didik, buku ajar, dan pembelajaran yang berkualitas.

Bahan ajar merupakan segala bahan yang disusun secara sistematis mencakup kompetensi yang akan dikuasai siswa dan digunakan dalam proses pembelajaran dengan tujuan perencanaan dan penelaahan implementasi pembelajaran (Prastowo, 2014). Bahan ajar sebagai salah satu media pembelajaran mempunyai peranan penting dalam proses pembelajaran yaitu sebagai acuan bagi siswa dan guru untuk meningkatkan efektifitas pembelajaran. Bagi siswa, bahan ajar menjadi bahan acuan yang diserap isinya dalam proses belajar sehingga dapat menjadi pengetahuan. Sedangkan bagi guru, bahan ajar menjadi salah satu penyampaian informasi kepada peserta didik (Belawati, 2003).

Pengembangan bahan ajar dalam hal ini adalah buku ajar merupakan usaha dalam meningkatkan efektivitas dalam pembelajaran Salah satu upaya untuk peningkatan kualitas pendidikan melalui bahan ajar diharapkan membawa dampak positif terhadap pendidikan di Indonesia (Prastowo, 2014). Bahan ajar yang baik akan dapat meningkatkan motivasi dan hasil belajar peserta didik. Selain itu pengembangan bahan ajar juga harus memperhatikan karakteristik dan kebutuhan peserta didik karena pada dasarnya peserta didik mempunyai kreatifitas dan kemampuan yang berbeda. Keberadaan bahan ajar yang tepat juga penting untuk menunjang pelaksanaan kegiatan belajar mengajar (Susilawati et.al. 2020).

Pengembangan buku ajar bahasa inggris yang diintegrasikan dengan materi keislaman bertujuan untuk membentuk jiwa-jiwa spiritualitas serta menanamkan kecintaan pada Allah, Al-Qur'an dan Nabi Muhammad sejak dini, karena dilengkapi dengan kisah nabi muhammad, do'a-doa sehari-hari, hadits nabi, contoh kegiatan-kegiatan berbasis islami seperti membaca Al-Qur'an, sholat berjama'ah dan lagu-lagu berbahasa inggris berbasis islami. Selain memahami materi keislaman peserta didik juga dapat memahami materi bahasa inggris secara kontekstual serta dilengkapi dengan 4 aspek keterampilan berbahasa. 
Hasil penelitian yang dilakukan oleh (Risnawati 2017) dengan judul Pengembangan Bahan Ajar Bahasa Inggris Berbasis Lingkungan untuk meningkatkan kosakata dan hasil belajar peserta didik di Sekolah Dasar menunjukkan bahwa bahan ajar tersebut mampu meningkatkan pemahaman dan interaksi peserta didik dengan lingkungan sekitar, dengan demikian penggunaan kosakata peserta didik dalam bahasa inggris terbantu karena siswa belajar dengan kondisi nyata pada proses pembelajaran. Penelitian selanjutnya oleh (Oktariani \& Juwita R.P, 2019) tentang pengembangan bahan ajar bahasa inggris sekolah dasar menunjukkan bahwa bahan ajar bahasa inggris berbentuk video animasi permainan tradisional dapat meningkatkan kosakata dan keterampilan berbicara peserta didik.

Berdasarkan hasil observasi peneliti, buku ajar Bahasa inggris yang digunakan di madrasah Ibtidaiyah atau sekolah dasar hanya berfokus pada materi pembelajaran saja, maka perlu untuk diterapkan pembelajaran bahasa inggris dalam konteks nyata atau secara kontekstual dikaitkan dengan hal-hal yang ada di sekitar peserta didik sehingga bahasa inggris bukan lagi sekedar bahasa asing yang diterapkan dalam teori tetapi sedikit demi sedikit dapat menjadi bagian alat komunikasi sehari-hari (Maduwu B., 2016). Buku ajar yang mempunyai ciri khas tertentu akan diingat dan memberikan motivasi belajar yang lebih kepada peserta didik, dalam hal ini peneliti ingin mengembangkan buku ajar bahasa inggris yang diintegrasikan dengan materi keislaman. Penanaman aspek spiritual sejak dini merupakan cara untuk melatih dan mengembangkan kepribadian serta karakter islami pada peserta didik.

Materi yang dikembangkan dalam buku ajar ini berfokus pada "Daily Activities" sehingga cocok sekali dikaitkan dengan kegiatan-kegiatan yang berbasis keislaman yang biasa dilakukan peserta didik di rumah dan di sekolah sehingga sesuai dengan pembelajaran berbasis kontekstual. Kegunaan pengembangan buku ajar bagi peserta didik adalah meningkatkan pemahaman materi bahasa inggris serta menambah kecintaan terhadap islam melalui pembelajaran yang menarik dan menyenangkan. Bagi guru buku ajar ini dapat dijadikan buku pedoman tambahan dan sumber belajar yang variatif untuk dapat menciptakan pembelajaran yang sesuai dengan abad 21 . 


\section{B. Metode Penelitian}

Penelitian ini menggunakan metode penelitian dan pengembangan (Research \& Development) dengan desain Borg \& Gall. Desain tersebut (Sugiyono, 2018) memiliki beberapa tahapan yaitu:

1) Pengumpulan data \& Informasi

Pada tahap ini peneliti melakukan wawancara kepada guru bahasa inggris dan melakukan observasi terhadap pembelajaran bahasa inggris di MI/SD.

2) Perencanaan

Pada tahap ini peneliti melakukan perencanaan terhadap buku ajar yang dikembangkan yaitu menentukan materi pembelajaran, target, integrasi dengan keislaman dan evaluasi buku ajar.

3) Pengembangan Produk

Tahap pengembangan buku ajar dimulai dari melakukan penataan isi dan struktur buku ajar, kemudian penyusunan kegiatan pembelajaran yang menarik dan sesuai dengan karakteristik peserta didik kelas 3, selanjutnya melakukan penyusunan buku ajar dengan penambahan materi yang lebih luas seperti praktik dan integrasi materi keislaman berupa doa-doa, hadits, kisah-kisah nabi, lagu dan kegiatan-kegiatan yang berbasis islami, terakhir melakukan penyusunan evaluasi.

4) Validasi produk

Validasi yang digunakan pada penelitian pengembangan ini adalah validasi ahli mata pelajaran bahasa inggris, ahli desain media pembelajaran, guru bahasa inggris, dan peserta didik sebagai pengguna produk. Tujuan dari validasi ini untuk memperoleh data berupa saran, arahan, dan penilaian terhadap produk yang dikembangkan, selanjutnya peneliti bisa melakukan revisi terhadap produk yang dikembangkan. Subjek validasi pada penelitian ini adalah dosen yang memiliki latar belakang pengetahuan pada bidangnya masing-masing serta guru bahasa inggris yang telah berpengalaman mengajar.

5) Revisi produk

Produk yang telah divalidasi oleh ahli kemudian peneliti melakukan revisi untuk perbaikan serta saran-saran dari validator digunakan untuk 
meningkatkan kualitas produk yang dikembangkan yaitu buku ajar bahasa inggris.

6) Uji coba produk

Uji coba dirancang untuk mengetahui kelayakan produk yang telah dikembangkan. Tahapan dalam uji coba ini yaitu melakukan uji coba pada skala kecil setelah itu peneliti melakukan uji coba skala besar pada peserta didik kelas 3 .

Teknik analisis data yang digunakan untuk menganalisis data kuantitatif dari hasil validasi dengan teknik perhitungan nilai rata-rata. Rumus perhitungan nilai rata-rata sebagai berikut:

$$
\begin{aligned}
\mathrm{P}= & \frac{\sum \mathrm{x}}{\sum x i} \mathrm{P}=\frac{\sum \mathrm{x}}{\sum x i} \\
& \multicolumn{1}{c}{\mathrm{X} 100 \%} \\
& \mathrm{P} \quad \text { : Kelayakan } \\
& \sum x \quad \text { : Jumlah jawaban penilaian } \\
& \sum x i \quad \text { : Jumlah jawaban tertinggi }
\end{aligned}
$$

Tabel 1.1

Kualifikasi Tingkatan Kelayakan berdasarkan Persentase

\begin{tabular}{|l|l|l|}
\hline Persentase (\%) & Kriteria kelayakan & Keterangan \\
\hline $80-100$ & Valid & Tidak revisi \\
\hline $60-79$ & Cukup valid & Tidak revisi \\
\hline $40-59$ & Kurang valid & Sebagian revisi \\
\hline $0-39$ & Tidak valid & Revisi total \\
\hline
\end{tabular}

\section{Hasil dan Pembahasan}

Hasil pengembangan buku ajar bahasa inggris berbasis islami ini didasarkan pada kenyataan bahwa belum tersedia buku ajar bahasa inggris yang berbasis islam untuk madrasah ibtidaiyah dan sekolah dasar. Produk pengembangan buku ajar ini telah divalidasi oleh ahli materi, desain, dan pembelajaran sehingga bisa dimanfaatkan dan digunakan secara luas oleh peserta didik.

Buku ajar bahasa inggris ini memuat materi-materi keislaman diantaranya doa-doa, hadits, kisah-kisah nabi, lagu dan kegiatan-kegiatan yang berbasis islami. Tidak hanya itu buku ajar ini dilengkapi dengan gambar dan ilustrasi visual yang islami sesuai dengan adat istiadat muslim di Indonesia. Harapan dari peneliti melalui pengembangan buku ajar ini adalah peserta didik dapat menanamkan nilainilai ajaran Islam sejak dini kepada peserta didik dan mampu meneladani dari 
kisah nabi yang dipelajari serta dapat menerapkan kegiatan-kegiatan berbasis spiritual sehari-sehari.

Buku ajar ini disesuaikan dengan karakteristik peserta didik MI/SD yaitu adanya minat kehidupan sehari-hari yang konkrit, hal ini diselaraskan dengan buku ajar yang kembangkan berupa kegiatan yang biasa dilakukan peserta didik seharihari. Peserta didik usia sekolah dasar/madrasah ibtidaiyah berada pada tahap operasional konkret, yaitu anak mengembangkan pemikiran logis, terikat pada fakta-fakta perseptual. Artinya anak mampu berpikir logis tetapi masih terbatas pada objek-objek konkrit dan mampu melakukan konservasi (Septianti et al., 2020).

Faktor penting dalam pembelajaran bahasa inggris di madrasah ibtidaiyah \& sekolah dasar adalah membangun minat dan motivasi belajar karena bahasa inggris bukan merupakan bahasa ibu yang biasa digunakan untuk komunikasi sehari-hari, sehingga perlu adanya kegiatan yang sangat menarik dan efektif dalam proses pembelajaran. Buku ajar yang baik harus mengandung aspek motivation to learn, yaitu ketika peserta didik membaca sebuah buku ajar, anak akan termotivasi belajar tanpa harus dipaksakan oleh guru karena buku adalah media belajar (Jannah R., 2016).

Buku ajar yang dikembangkan oleh peneliti berisi aktivitas dan kegiatan yang membantu penguasaan kosakata (Vocabulary), Berbicara (Speaking), Menulis (Writing) \& Mendengarkan (Listening) sehingga tercipta pembelajaran yang efektif, efisien, menyenangkan. Tidak hanya itu buku ajar bahasa inggris ini mampu meningkatkan hasil belajar peserta didik karena dikemas dengan bahasa yang sederhana sesuai dengan perkembangan bahasa usia SD/MI.

\section{Hasil Validasi Ahli}

Analisis hasil validasi ahli desain media terhadap buku bahasa inggris berbasis islami menunjukkan persentase $92 \%$ dengan kriteria:

1) kesesuaian gambar, warna tulisan pada buku ajar yang terintegrasi dengan keislaman;

2) pengemasan desain cover sangat menarik;

3) layout, huruf, dan tulisan sangat sesuai dengan karakteristik peserta didik $\mathrm{MI} / \mathrm{SD}$. 
Buku ajar yang telah divalidasi oleh ahli desain berada pada kualifikasi sangat valid sehingga buku ajar tidak perlu dilakukan revisi. Desain layout harus saling berkaitan dan memberi tekanan, penekanan bisa berupa pemberian warna yang berbeda dan ukuran font yang lebih besar (Kurniawan et al., 2019). Layout pada buku ajar terbukti dapat mempengaruhi motivasi dan pemahaman peserta didik. (Yvonne B. 2016) menjelaskan bahwa buku ajar yang baik didukung oleh desain layout yang menarik, hal ini dikarenakan keserasian antara desain layout buku yang diatur dan seberapa jelas elemen visual yang dirancang dapat mempengaruhi tingkat perhatian partisipan.

Validasi ahli materi terhadap buku ajar bahasa inggris berbasis islami dilakukan dua tahap. Tahap pertama memperoleh saran dari validator yaitu: penambahan lebih detail dan jelas pada Glosarium yang ada di buku ajar, aspek Listening dapat digunakan sebagai panduan untuk speaking, sehingga lebih baik meletakkan aspek listening sebelum speaking. Selanjutnya peneliti melakukan revisi terhadap buku ajar yang telah dikembangkan sebelumnya kemudian dilakukan validasi tahap kedua dengan kriteria:

1) Kesesuaian buku ajar bahasa inggris berbasis islami dengan kurikulum 2013;

2) Kesesuaian Bahan ajar bahasa inggris berbasis islami dengan keterampilan berbahasa;

3) Kesesuaian tujuan pembelajaran Bahan ajar bahasa inggris berbasis islami;

4) Kesesuaian materi yang disajikan dengan silabus Bahasa Inggris;

5) Kesesuaian Bahan ajar bahasa inggris berbasis islami dengan keadaan siswa SD kelas 3;

6) Kesesuaian bahasa yang dipakai dalam Bahan ajar bahasa inggris berbasis islami;

7) Kesesuaian jenis-jenis dan bentuk gambar Bahan ajar bahasa inggris berbasis islami;

8) Penyajian materi dan petunjuk penampilan mudah dipahami bagi siswa;

9) Kesesuaian isi Bahan ajar bahasa inggris berbasis islami dengan materi pembelajaran;

10) Penyajian materi sesuai dengan karakter mata pelajaran. 
Buku ajar yang telah divalidasi oleh ahli desain berada pada kualifikasi sangat valid sehingga buku ajar tidak perlu dilakukan revisi. Validasi ahli pembelajaran bahasa inggris dilakukan kepada guru bahasa Inggris yang telah berpengalaman mengajar sehingga mengetahui kebutuhan dan karakteristik siswa kelas $3 \mathrm{MI}$. Adapun kriteria penilaian pada buku ajar diantaranya: (1) kesesuaian tampilan fisik bahan ajar bahasa inggris berbasis islami (2) kejelasan tujuan pembelajaran bahan ajar bahasa inggris berbasis islami (3) kejelasan materi bahan ajar bahasa inggris berbasis islami (4) kesesuaian antara gambar dan materi dalam bahan ajar bahasa inggris berbasis islami (5) kejelasan tugas dan latihan dalam bahan ajar bahasa inggris berbasis islami (6) kemudahan memahami materi dalam bahan ajar bahasa inggris berbasis islami (7) kemudahan bahasa yang digunakan dalam bahan ajar bahasa inggris berbasis islami (8) kemenarikan isi dalam bahan ajar bahasa inggris berbasis islami (9) kesesuaian bahan ajar digunakan dalam pembelajaran (10) bahan ajar dapat memberikan motivasi belajar bahasa inggris peserta didik.

Buku ajar yang telah divalidasi oleh ahli pembelajaran berada pada persentase 94\% dengan kualifikasi sangat valid sehingga buku ajar tidak perlu dilakukan revisi. Bahan ajar memiliki pengaruh dan peran sangat tinggi dalam proses pembelajaran, hal ini disebabkan adanya hubungan guru, sumber belajar dan peserta didik (Walid et.al. 2017).

Kebutuhan buku ajar pada saat ini masih menjadi prioritas utama dalam melaksanakan kegiatan belajar mengajar. Buku ajar tidak hanya menjadi rujukan pokok bagi peserta didik dalam belajar, melainkan juga menjadi acuan bagi para guru dalam proses pembelajaran (Nurdeani, N. 2014). Tujuan pengembangan buku ajar bahasa inggris berbasis islami selain memberikan penanaman nilai-nilai spiritual sejak dini yang dikemas dengan kegiatan pembelajaran yang menarik dengan menggunakan bahasa inggris sebagai pengantarnya juga sebagai acuan guru dalam peningkatan kualitas pembelajaran.

\section{Tingkat kemenarikan Buku Ajar Bahasa Inggris berbasis Islami}

Hasil validasi buku ajar terhadap pengembangan buku ajar bahasa inggris berbasis islami dengan subjek kelas $3 \mathrm{MI} / \mathrm{SD}$ ini memperoleh persentase 90,04\%. Hasil penilaian uji coba lapangan pada setiap komponen sebagaimana dianalisis secara kuantitatif dapat diinterpretasikan sebagaimana berikut: 
a. Tampilan sampul dalam buku ajar bahasa inggris berbasis islami memperoleh skor 96\% sehingga dapat disimpulkan bahwa sampul ini sangat menarik perhatian peserta didik;

b. Kemudahan dalam belajar menggunakan buku ajar bahasa inggris berbasis islami memperoleh persentase 92\% sehingga menunjukkan bahwa buku ajar dapat memudahkan peserta didik dalam belajar;

c. Penggunaan buku ajar bahasa inggris dapat

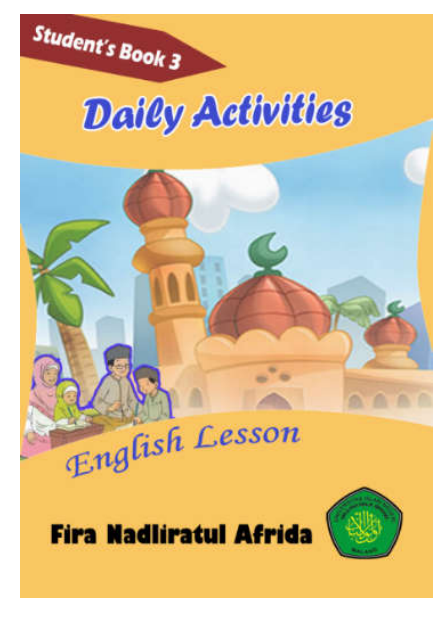
memberikan semangat belajar peserta didik memperoleh penilaian dengan persentase sebesar $94,6 \%$;

d. Buku ajar bahasa inggris berbasis islami memudahkan peserta didik memahami bahan pelajaran memperoleh penilaian dengan persentase sebesar 90,6\% sehingga buku ajar ini dapat digunakan peserta didik dalam memahami materi bahasa inggris serta dapat diterapkan dalam kehidupan sehari-hari khususnya pada sisi spiritual;

e. Soal-soal yang terdapat pada buku ajar bahasa inggris berbasis islami dapat mudah dipahami dan dikerjakan oleh peserta didik memperoleh penilaian dengan persentase sebesar 90,6\%;

f. Jenis dan ukuran huruf yang terdapat pada buku ajar bahasa inggris berbasis islami memudahkan peserta didik untuk membaca dan memahami materi. Pada aspek ini mendapat penilaian sebesar 98,6\%;

g. Kata-kata yang digunakan dalam buku ajar bahasa inggris berbasis islami sesuai dengan karakteristik peserta didik MI/SD, pada aspek ini peserta didik perlu untuk memperdalam vocabulary yang ada di buku ajar, hal ini diperoleh penilaian sebesar $84 \%$;

h. Bahasa yang yang digunakan dalam buku ajar bahasa inggris berbasis islami mudah dipahami memperoleh penilaian dengan persentase sebesar 98,6\%;

i. Penggunaan buku ajar memerlukan bantuan orang lain seperti teman, guru atau orangtua memperoleh penilaian dengan persentase 74,6\%. Hal ini dikarenakan bahasa inggris bukan merupakan bahasa yang digunakan oleh 
peserta didik sehingga perlu adanya arahan $\&$ bantuan dari guru atau orangtua untuk mendampingi proses belajar;

j. Buku ajar bahasa inggris berbasis islami sangat menarik untuk dipelajari memperoleh penilaian dengan persentase $90,4 \%$.

Daya tarik peserta didik terhadap buku ajar bahasa inggris dibuktikan dari hasil wawancara kepada beberapa peserta didik yang menyatakan bahwa buku ajar ini berbeda dengan buku ajar yang lain karena memiliki desain yang atraktif, menarik, dan mampu membangkitkan motivasi peserta didik untuk belajar karena dilengkapi dengan do'a-doa sehari-sehari, lagu islami, dan kegiatan-kegiatan yang bersifat kontekstual dekat dengan peserta didik.

Daya tarik peserta didik juga terlihat pada saat observasi atau pengamatan saat pembelajaran sedang berlangsung peserta didik sangat antusias dan tertarik untuk mempelajari buku bahasa inggris berbasis islami. Mereka sangat semangat untuk praktik berbicara bahasa inggris di depan kelas sehingga tercipta suasana pembelajaran yang menyenangkan dan bermakna. Kemenarikan bahan ajar juga dapat menjadi rangsangan bagi peserta didik untuk membaca dan mempelajari bahan ajar karena aspek kemenarikan dapat menentukan tersampainya isi dari buku ajar (Amelia, D.J, 2018).

\section{Kesimpulan}

Berdasarkan proses pengembangan dan hasil penilaian terhadap buku ajar bahasa inggris berbasis islami untuk siswa kelas III MI/SD ini dapat disimpulkan bahwa buku ajar bahasa inggris berbasis islami untuk siswa kelas III MI/SD memperoleh kualifikasi yang baik, dibuktikan dengan hasil validasi oleh ahli materi dengan persentase $80 \%$, ahli desain dengan persentase $92 \%$, guru kelas dengan persentase 94\%. Buku ajar memiliki tingkat kemenarikan yang tinggi dibuktikan dengan hasil wawancara dan angket kepada peserta didik dengan persentase 90,04\%. Selain itu saran dan komentar dari validator juga digunakan peneliti untuk memperbaiki dan meningkatkan kualitas buku ajar yang dikembangkan.

\footnotetext{
$* * * * * * * * *$
} 


\section{Daftar Pustaka}

Amelia, D.J. (2018). Pengembangan Bahan Ajar Cetak dalam Bentuk Komik untuk Siswa Kelas III Sekolah Dasar. Jurnal Pemikiran dan Pengembangan SD. 6(2). DOI:10.22219/jp2sd.v6i2.7152

Behnke, Yvonne. (2016). How Textbook May Influence Learning with Geography Textbook. Berlin: Humboldt-Universität zu Berlin.

Belawati, Tia. 2003. Materi Pokok Pengembangan Bahan Ajar Edisi ke Satu. Jakarta: Universitas Terbuka.

Fadila D. \& Yuhana, Y.M. (2018). Pengembangan Materi Ajar Bahasa Inggris Berbasis Lingkungan untuk Meningkatkan Penguasaan Kosakata dan Hasil Belajar Peserta Didik di Sekolah Dasar. Jurnal Teknologi Pendidikan dan Pembelajaran.5(1)

Jannah R. (2016). Pengembangan Buku Ajar Tematik Bernuansa Islami untuk Madrasah Ibtidaiyah/Sekolah Dasar Islam. Muallimuna: Jumal Madrasah Ibtidaiyah 2(1). http://dx.doi.org/10.31602/muallimuna.v2i1.737

Kurniawan, I.W. \& Patria, A.S. (2019). Analisis Layout Buku Tematik Kelas 5 Sekolah Dasar Tema 8. Jurnal mahasiswa UNESA. 4(7).

Maduwu, B. (2016). Pentingnya Pembelajaran Bahasa Inggris di Sekolah. Jurnal Dharmawangsa. 1(5). DOI: https://doi.org/10.46576/wdw.v0i50.207.

Nurdaeni, N (2014) Analisis Buku Teks Pelajaran Bahasa Inggris berdasarkan Standar Penulisan Buku Teks Pelajaran. Pedadidaktita: Jurnal Ilmiah Mahasiswa Pendidikan Guru Sekolah Dasar. 1(1).

Oktariyani \& Juwita. P.R. (2019). Pengembangan Bahan Ajar Bahasa Inggris Berbasis Local learning pada Siswa Sekolah Dasar. Jurnal Ilmiah Indonesia. 4(10).

Prastowo, A. (2014). Panduan Kreatif Membuat Bahan Ajar Inovatif. Yogyakarta: Diva Press.

Puspita A.M.I \& Purwo S. 2019. Pengaruh Bahan Ajar Berbasis Literasi dengan Pendekatan Kontekstual terhadap Hasil Belajar Siswa Sekolah Dasar. Al-Aulad: Journal of Islamic Primary Education, 2 (1).

Septianti, N. \& Rara A. (2020). Pentingnya Memahami Karakteristik Siswa Sekolah Dasar di SDN Cikokol 2. As-Sabiqun: Jurnal Pendidikan Islam Anak Usia Dini. 2(1). https://doi.org/10.36088/assabiqun.v2i1

Sugiyono. (2018). Metode Penelitian Kuantitatif, Kualitatifdan R\&D. Bandung: Alfabeta.

Susilawati, F., Gunahardi \& Hartono. (2020). Pentingnya Pengembangan Bahan Ajar Tematik dalam Peningkatan Karakter Peduli Lingkungan Siswa. Eduhumaniora: Jurnal Pendidikan Dasar. 12(1). DOI: 10.17509/eh.v12i1.15068

Walid, M. \& Hanifah, N.H. (2017) Pengembangan Buku Ajar Tematik Kelas IV Berbasis Integrasi Islam Pada Subtema Pemanfaatan Energi di Sekolah Dasar. JMIE: Journal of Madrasah Ibtidaiyah Education. 1(2). http://dx.doi.org/10.32934/jmie.v1i2.45 
Pengembangan Buku Ajar Bahasa Inggris Kelas 3 MI/SD Berbasis Islami 